\title{
О СЕМАНТИЧЕСКИХ ПРОЦЕССАХ \\ В ОБЩЕСТВЕННО-ПОЛИТИЧЕСКОЙ ЛЕКСИКЕ \\ (НА ПРИМЕРЕ СЛОВА ФАШИЗМ И ЕГО ДЕРИВАТОВ)
}

\author{
ABOUT SEMANTIC PROCESSES IN THE POLITICAL LEXICON \\ (ON THE EXAMPLE OF THE WORD FASCISM AND ITS DERIVATIVES)
}

\section{ОЛЬГА ФРОЛОВА}

\begin{abstract}
The article discusses the semantics of the word fascism in explanatory dictionaries and analyzes its current use. Comparing different interpretations in dictionaries, one can see how the authors avoid mentioning a particular period in which the term fascism emerged. The important semantic features of the term fascism are racism, dictatorship, and opposition to a free society. The word fascist is used to refer to: a) a supporter of a certain ideological and political doctrine that arose and was implemented in Italy and Germany in the first half of the twentieth century, characterized by racism and chauvinism, and taking the form of dictatorship; b) a follower of racist attitudes; c) the enemy, an object of hatred; d) the enemy in children's games; e) camouflage element in the oxymoronic phrase 'liberal fascism', masking the rejection of liberal values by the speaker.
\end{abstract}

Ольга Фролова, Московский государственный университет им. М. В. Ломоносова, Москова - Россия, Olga_frolova@list.ru

Динамичные изменения в современном русском языке привлекают пристальное внимание языковедов ${ }^{1}$. Единицы, значение которых представляется установившимся, также демонстрируют семантические трансформации. Мы намереваемся проанализировать употребление слов фашизм, фрашист в русской речи.

Обратимся к толковым и энщиклопедическим словарям. У Д. Н. Ушакова фашизм - „(ит. fascismo от латин. fascis - 'пучок прутьев, в Древнем Риме служивший символом власти') (нољ. полит.) одна из форм от-

\footnotetext{
${ }^{1}$ См. следующие работы: И. Т. В е п р е в а, Языковая рефлексия $b$ постсоветскую эпоху, Москва 2005; В. Г. К о с т о м а р о в, Языковой вкус эпохи, Москва 1994; Р. Р а т м а й р, Русская речь и рынок: традииии и инновачии в деловом и повседневном общении, Москва 2013; Русский язык конца ХХ столетия, отв. ред. Е. А. Земская, 2-е изд., Москва 2000; Современный русский язык. Активные процессы на рубеже ХХ-ХХІ веков, отв. ред. Л. П. Крысин, Москва 2008; Современный русский язык: система-норма-узус, отв. ред. Л. П. Крысин, Москва 2010; Современный русский язык: социальная и функииональная диффреренциациия, отв. ред. Л. П. Крысин, Москва 2003.
} 
крытой буржуазной диктатуры в нек-рых капиталистических странах, возникшая в Италии после первой империалистической войны в обстановке общего кризиса капитализма" 2 . В словаре под редакцией А. П. Евгеньевой несколько иное толкование: „Политическое течение, возникшее в капиталистических странах в период общего кризиса капитализма и выражающее интересы наиболее реакционных и агрессивных кругов империалистической буржуазии, а также открыто террористическая диктатура наиболее реакционных сил монополистического капитала, для которых характерны воинствующий антикоммунизм, шовинизм, расизм, подавление всех демократических свобод, подготовка и развязывание захватнических войн"з. В академическом многотомном словаре второй половины XX в. данное слово объясняется следующим образом: „Крайне реакционное политическое течение, выражающее интересы наиболее агрессивных кругов империалистической буржуазии и характеризующееся разнузданным шовинизмом, расизмом, уничтожением демократических свобод, развязыванием захватнических войн; террористическая диктатура монополистического капитала" 4 . В толковом словаре последнего времени представлена такая семантизация: „Политическое течение, в основе которого лежит идеология культа сильной личности, вождизма, агрессивного шовинизма и расизма" 5 . В качестве актуальной единицы данное слово входит в словник словаря актуальной лексики последнего времени, фашизм - „Полит. Идеология и политика шовинизма и расизма, направленные на уничтожение демократии и установление тоталитарных, репрессивных режимов"6.

В качестве энциклопедических изданий мы избрали электронные издания, свободные от идеологизации советской эпохи. В русскоязычной Википедии дается такое определение: фрашизм - „(итал. fascismo от fascio 'союз, пучок, связка, объединение') обобщенное название крайне правых политических движений, идеологий и соответствующая им форма правления диктаторского типа, характерными признаками которых являются милитаристский национализм (в широком понима-

2 Толковый словарь русского языка: $b$ 4-х т., под ред. Д. Н. Ушакова, т. 4, Москва 1996, с. 1064.

${ }^{3}$ Словарь русского языка: $b$ 4-x т., под ред. А. П. Евгеньевой, 2-е изд., испр. и доп., т. 4, Москва 1981-1984, с. 556.

4 Словарь современного русского литературного языка: в 17-ти т., т. 16, Москва 1948-1965, с. 1285.

${ }^{5}$ Большой толковый словарь русского языка, гл. ред. С. А. Кузнецов, Санкт-Петербург 2002, с. 1418.

${ }^{6}$ Толковый словарь русского языка начала ХХІ века: актуальная лексика, под ред. Г. Н. Скляревской, Москва 2008, с. 1020. 
нии), антикоммунизм, ксенофобия, реваншизм и шовинизм, мистический вождизм, презрение к выборной демократии и либерализму, вера в господство элит и естественную социальную иерархию, этатизм и в ряде случаев геноцид"7. Англоязычная Википедия, не совпадая с русской, делает несколько иные акценты в дефиниции: fascism „is a form of radical authoritarian nationalism that came to prominence in early $20^{\text {th }}$-century Europe. Influenced by national syndicalism, fascism originated in Italy during World War I, in opposition to liberalism, Marxism, and Anarchism. Fascism is usually placed on the far-right within the traditional left-right spectrum" 8 .

С целью выявления ключевых сем слова мы обратились также и к пародийному электронному изданию Луркморье, сохраняя лексику и орфографию источника. Фошыст - „разновидность поцреотов, которые не любят агентов ZOGa, чурок, азиатов, жыдов, жителей солнечной Африки, почитают Гитлера и любят дописывать 1488 к своим никам. Испытывают неприязнь к многонациональным ымперцам, коммунякам и антифашистам, что выливается в ожесточенный пиздёж в интернете, бурления говен и холивары. Фашисты делятся на множество подвидов: от квасных поцреотов до хардкорных скинов, но при этом редко сами себя называют фашистами, предпочитая маски, вроде «националист», «расист», «национал-социалист» и т. п." 9.

Как видно из толкования в Луркморье, явление, описываемое с помощью заголовочной единицы, является предметом острых идеологических дискуссий в современном российском обществе. Статья содержит указания на многочисленные символы, которые сторонники движения объясняют как древние индийские солярные и славянские знаки. В энциклопедии предлагается также заголовочная единица гламурныи фpaшизм, происхождение которого связано с популярным сериалом советского времени „Семнадцать мгновений весны”. С одной стороны, Луркморье отмечает идеологическое противостояние фашистов по отношению к представителям других рас и национальностей, с другой - дает расширенное толкование, говоря о нескольких видах фашистов.

Энциклопедические и толковые словари выделяют сходные семы в толковании, во-первых, определяя статус единицы: для русской языковой картины мира именно слово фашизм является гиперонимом. На эту роль не претендуют близкие термины нацизм и национал-социализм.

\footnotetext{
7 Википедия, [в:] электронный ресурс: https://ru.wikipedia.org/wiki/\%D0\%A4\% D0\%B0\%D1\%88\%D0\%B8\%D0\%B7\%D0\%BC

8 Википедия, [в:] электронный ресурс: https://en.wikipedia.org/wiki/Fascism

9 Луркморье, [в:] электронный ресурс: https://lurkmore.to/\%D0\% A4\%D0\%B0\%D $1 \% 88 \% \mathrm{D} 0 \% \mathrm{~B} 8 \% \mathrm{D} 1 \% 81 \% \mathrm{D} 1 \% 82$
} 
Во-вторых, при сопоставлении толкований выделяются несколько сем: форма - политическое течение и его признаки - шовинизм и расизм. В-третьих, отмечается форма правления - диктатура. В-четвертых, антонимические отношения связывают искомое слово с терминами либерализм, демократия, свобода, анархия. Заметим, что антонимические отношения фрашизма и марксизма упоминает лишь англоязычная Википедия. Показательно, что из толкований уходят упоминания Италии как страны, в которой родилась идеология фашизма, сохраняется лишь отсылка к этимологии слова ${ }^{10}$.

Что касается слова фашист, его значение описывается в словарях как более широкое по объему: „Приверженец фашизма, член фашистской организации. || Разг. О солдатах и офицерах гитлеровской Германии. Отряд фашистов. Сражаться с фашистами. | Бранно. О крайне агрессивном, злобном человеке"11. Оттенок значения с пометой бранно позволяет такую интерпретацию, в которой идеологическая составляющая отходит на второй план. Сопоставление словарных толкований позволяет выявить разночтения: например, Г. Н. Скляревская сужает объем значения, не включая перенос. Фашист - „Полит. Сторонник, последователь фашизма; член нацистской партии" 12.

Чтобы проанализировать употребление, обратимся к Национальному корпусу русского языка ${ }^{13}$.

(1) „Советские школьники, чьи родители воевали, ребята, реально помнившие войну, играли в фашистов, собирали портреты Гитлера и его приспешников" 14 .

В первом примере отражено употребление, сложившееся в детской речи: после Второй мировой войны в детских играх в войну противник довольно часто получал наименование фашиста.

В примере 2 фашист включен в довольно обширную группу не наших, т. е. враждебных сил.

(2) „Да ещё в команду сил зла помимо традиционных персонажей типа леших, вурдалаков, упырей включили фашистов, каратистов, де-

10 В специальной исторической литературе выделяются те же характеристики фашизма как политического движения. См.: R. Griffin, The Nature of Fascism, London 1993; История фашизма в Западной Европе, Москва 1978; Ж. Ж е л е в, Фашизм. Тоталитарное государство, Москва 1991; Э. Н о л ь т е, Фашизм в его эпохе, Новосибирск 2001; Ф. Л. Н о й м а н н, Бегемот. Структура и практика национал-социализма. 1933-1944, Санкт-Петербург 2015.

11 БТС 2002: 1418.

12 Толковый словарь русского языка начала ХХІ века..., указ. соч., с. 1020.

13 Национальныи корпус русского языка, [в:] электронный ресурс: www.ruscorpora.ru

14 Д. Д рагунский, Помет валькирий, „Частный корреспондент" 2011, [в:] электронный ресурс: www.ruscorpora.ru (23.03.2011). 
виц лёгкого поведения, супермена Рембо, шпионов ниндзя и даже лидера мирового терроризма Усаму бен Ладена"15.

Пример 3 демонстрирует отход от идеологической точности в употреблении: тоталитарное государство 1930-1950 г. в СССР, по-видимому, исключало практику расизма. В речи персонажа слово фашист употреблено как характеризующий, а не таксономический предикат.

(3) „Сюзанна Карловна не здоровается со старухой Ольгой Николаевной, - та назвала Сталина фашистом, а Ленина убийцей русской свободы"16.

Пример 4 показывает, что довольно часто слово фашист в употреблении освобождается от своей идеологической семантики, обозначая политического противника.

(4) „В фашисты записывали всех: и Тито, и Эйзенхауэра, и вообще всех капиталистов" 17 .

В современном употреблении авторы зачастую не прибегают к композиту неофашист, используя термин, имеющий точную датировку и относящийся к середине XX в.

(5) „С уверенностью, что все плохое возможно, с чувством готовности на улице, сконцентрировавшись, с врезавшимся в память знанием болевых мест, разделенные на страты и кланы, на «элиту» и «быдло», на «фашистов» И «черножопых», на «патриотов» и «либерастов», и так до мельчайшей стадии дробления, до той, где каждый человек сам за себя и против всех, - мы дружно воплощаем парадигму воюющей страны" 18 .

Показательно, что в политическом дискурсе слово фашист может обозначать политического противника как на русском, так и на других языках. Свидетельством этого служит перевод речи Каддафи.

(6) „Выступившие против Ливии западные державы лишь «кучка фашистов, которая кончит свои дни на свалке истории", - убежден ливийский лидер Муамар Каддафи, войска которого продолжают успешно противостоять повстанцам, несмотря на авиаудары сил западной коалиции" 19.

15 Темные силы против Масленицы, „Народное творчество” 2004, [в:] электронный pecypc: www.ruscorpora.ru

16 В. Г р о с с м н н, Все течет (1955-1963), „Октябрь” 1989, [в:] электронный реcypc: www.ruscorpora.ru

17 Д. Д р а г у н с к и й, указ. соч.

18 В. А п л е т а е в, Гражданское добивание, „Русский репортер”, 22 сентября 2011, № 37 (215), [в:] электронный ресурс: www.ruscorpora.ru

19 Ю. К а л а ч и х и н а, Каддафри отправил Запад на „свалку истории”, [в:] электронный ресурс: http://www.rbcdaily.ru/2011/03/23/world/562949979918858.shtml (23.03.2011). 
Употребление слова фашист в позиции предиката демонстрирует практически полную десемантизацию, утрату идеологической составляющей, которая заменена психологической.

(7) „Он - эгоманьяк, который ради всеобщего признания готов на все и начинает считать себя богом. Стремление к идеалу делает нас фашистами. Через двадцать пять лет люди научатся продлевать себе молодость и жить до ста лет" 20.

При этом в русском языке функционируют сложные слова неофашист, неонацист: по данным НКРЯ, обнаруживаются 22 документа (25 контекстов) с первым из них и 24 документа (28 контекстов) со вторым. Достаточно сравнить эти результаты со статистикой употребления существительного фашист (996 документов, 2987 контекстов), как выбор говорящего становится ясен.

В связи со сложными социальными процессами в России и кризисом на Украине попытки предложить номинации для националистических группировок привели к возникновению игровых слов, представляющих собой контаминации: нашист (участник проправительственной молодежной организации „Наши”, который с точки зрения говорящего пропагандирует националистические взгляды), рашист (русский фашист), укрофашист (сторонник националистического движения на Украине, чьи взгляды говорящий считает фашистскими).

В последнее время в российском Интернете ведутся дискуссии о содержании термина. На портале mail.ru в режиме „вопрос-ответ” пользователи дают свои толкования слова, порой отличающиеся полярностью.

(8) „чук чучхе Мастер (1497),

я вот не пойму... почему людей декларирующих СЛАВУ РОССИИ!!! называют фашистами???

- Фашисты это все проповедники, защитники и симпатизанты идеи глобального насилия против России как геополитического субъекта и против русских как самобытного народа с его правом самостоятельно определять пути развития своей цивилизации" 21.

(9) „В отличие от таких понятий, как консерватизм, либерализм, социализм, коммунизм и т. д., понятие «фашизм» лишено содержания" 22.

(10) „Это общность нации, основанная на тотальной идеологической сплоченности, агрессивном отношении к иным. «Фашизм» мы понимаем не только как проявления немецкого пост империализма, а развернуто, как некую систему противодействующую равноправ-

20 Е. Г у с я т и н с к и й, О маньяках и кризисе, „Русский репортер”, 22 сентября 2011, № 37 (215), [в:] электронный ресурс: www.ruscorpora.ru

21 См.: электронный ресурс: https://otvet.mail.ru/question/20705322 (23.03.2011).

22 См.: электронный ресурс: https://otvet.mail.ru/question/10993861 (23.03.2011). 
ному демократическому устройству мира, и выделяющую «хороших» и «нехороших» людей" 23 .

Как видим, в предложенных объяснениях наблюдаются три тенденции: попытки выявить признаки движения (пример 10), десемантизировать термин (пример 9), прагматически заострить номинацию, обратив ее против оппонента или идеологического противника в противостоянии своего и чужого (пример 8).

В 2008 г. была опубликована в оригинале, а в 2012 г. вышла в переводе на русский язык книга Дж. Голдберга Либеральный фашизм²4. В англоязычной Википедии авторы отмечают неординарную трактовку содержания термина: автор „argues that over time, the term fascism has lost its original meaning and has descended to the level of being a modern word for 'heretic'"25. Авторы статьи прямо говорят о десемантизации термина. Предложенное в книге словосочетание либеральный фрашизм звучит оксюморонно. Автор снимает антонимию диктаторского характера фашизма и демократии, на которую указывают и энциклопедические, и толковые словари. Дж. Голдберг пишет: „То подновленное здание американского прогрессивизма, которое мы называем либерализмом, фактически стоит на фундаменте фашизма и является одним из его проявлений" 26.

Термин либеральный фашизм или либералфашизм был взят на вооружение в качестве инструмента для объяснения конфликтов и актов терроризма в демократических странах. Данный термин встречается как в политологических, так и неспециальных текстах. Поиск в системе Google, проведенный 20 сентября 2015 г., дает примерно 453000 результатов.

(11) „По Европе прокатились манифестации под маркером манифестующих «Я - Шарли». Идеологически сущность этого движения можно определить как «либеральный фашизм». Либеральный - потому, что его базовая идеологема - «свобода слова». Фашизм - потому, что отрицается право другого на иную ценностную платформу, на иную культурную идентичность" 27.

В примере 11 автор задается целью предложить новое содержание понятия фашизм, заменив политические и идеологические основания экономическими.

${ }^{23}$ См.: электронный ресурс: https://otvet.mail.ru/question/50979100 (23.03.2011).

24 Дж. Г о л д б е р г, Либеральный фатизм. История левых сил от Муссолини до Обамы, Москва 2012.

25 Wikipedia, [в:] электронный ресурс: https://en.wikipedia.org/wiki/Liberal_Fascism

26 Д ж. Г о л д б е р г, указ. соч., с. 9.

27 В. Э. Б а г д а с а р я н, „Шарли Эбдо” - либеральный фашизм, [в:] электронный pecypc: http://rusrand.ru/docconf/sharli-ebdo--liberalnyy-fashizm 
(12) „Выражение «либеральный фашизм» у эстетов принято считать истеричным и бессодержательным.

- Как фашизм может быть либеральным? Что общего может быть у идеологии прав человека с фашизмом?

Но ведь они же противоположны, либерализм и фашизм, да?

Идеологии вроде бы разные, а объект ненависти всё тот же.

Объект ненависти - мы.

Либерализм и фашизм объединяет стоящий у них за спиной истинный исторический субъект - капитал. Капитал как историческая сила. При помощи фашизма он сокрушает сопротивление других исторических сил и субъектов, при помощи либерализма обеспечивает и сохраняет собственное доминирование" 28 .

Как видим, интересующий нас термин встречается в текстах, оформленных по правилам научного дискурса: с введением дефиниций, дополнительных терминов идеологема, маркер, субъект, доминирование.

Политолог и журналист М. Л. Шевченко без ссылок на Голдберга активно употребляет словосочетание либеральный фашизм в своих передачах.

(13) „Я считаю, что доминирующая сила в Украине, да и в других частях постсоветского пространства некоторых - это либерал-фашизм, это господство спайки бюрократии, олигархии, силовиков и криминала. Либерал-фашизм, который обеспечивает полный контроль над обществом и государством небольшой группе людей с полным тотальным медиагосподством и с наличием при всем при этом не социально ориентированного политического мировоззрения, которое считало бы, что миллионы людей, живущих в Украине там или в России, достойны бесплатного образования, бесплатной медицины, бесплатных разных структур, приводящих к развитию их личности" 29.

Объяснения Шевченко во многом, как видим, совпадают с тезисами Дж. Голдберга.

(14) „Рябцева решила напомнить либералам о том, что необходимо тактично разговаривать с оппонентами, отказаться от нетерпимости. Интересно, что сама нетерпимость, по словам Рябцевой, это - «либеральный фашизм»" 30 .

28 Р.Н ос ико в, Капитализм и Глобальное 3ло. Рецензия на "Мсителей-2", [в:] электронный ресурс: http://www.odnako.org/blogs/kapitalizm-i-globalnoe-zlo-recenziyana-mstiteley-2/

29 „Особое мнение” 28 мая 2014 г., [в:] электронный ресурс: http://echo.msk.ru/ programs/personalno/1329372-echo/

30 Журналист „Эха Москвы” обнаружила либеральных фашистов в собственных рядаx, [в:] электронный ресурс: http://politrussia.com/opozitsiya/zhurnalistka-ekhamoskvy-419/ 
Пример 14 демонстрирует иную тенденцию: термин лишается своего идеологического содержания, подобно тому как фашистом дети называют противника в игре.

Подводя итоги, можем сказать, что личное существительное фpaшист оказывается шире по объему, чем абстрактный термин. В речи слово фашист употребляется для обозначения: а) сторонника определенной идеологической и политической доктрины, возникшей и реализованной на государственном уровне в Италии и Германии в первой половине $X X$ в., характеризующейся расизмом, шовинизмом, осуществляющейся в форме диктатуры; б) последователя расистских взглядов; в) противника, объекта ненависти; г) противника в детских играх; д) камуфлирующего элемента в оксюморонном словосочетании либеральный фашизм, маскирующего неприятие говорящим либеральных ценностей.

\section{Библиография}

А п л е т а е в В., Гражданское добивание, „Русский репортер”, 22 сентября 2011, № 37 (215), [в:] электронный ресурс: www.ruscorpora.ru

Ба г д а с а р я н В. Э., "Шарли Эбдо” - либеральный фашизм, [в:] электронный pecypc: http://rusrand.ru/docconf/sharli-ebdo--liberalnyy-fashizm

Больщой толковый словарь русского языка, гл. ред. С. А. Кузнецов, Санкт-Петербург 2002.

В е п р е в а И. Т., Языковая рефлексия в постсоветскую эпоху, Москва 2005.

Википедия, [в:] электронный ресурс: https://en.wikipedia.org/wiki/Fascism

Википедия, [в:] электронный ресурс: https://ru.wikipedia.org/wiki/\%D0\%A4\%D0\% B0\% D1\%88\%D0\%B 8\%D 0\%B7\%D0\%BC

Г о л д б е р г Дж., Либеральный фашизм. История левых сил от Муссолини до Обамы, Москва 2012.

Г р о с с м н В., Все течет (1955-1963), „Октябрь” 1989, [в:] электронный ресурс: www.ruscorpora.ru (23.03.2011).

Г у с я т и н с к и й Е., О маньяках и кризисе, „Русский репортер”, 22 сентября 2011, № 37 (215), [в:] электронный ресурс: www.ruscorpora.ru

Д р а гунск ий Д., Помет валькирий, „Частный корреспондент” 2011, [в:] электронный ресурс: www.ruscorpora.ru (23.03.2011).

Ж е л е в Ж., Фашизм. Тоталитарное государство, Москва 1991.

Журналист „Эха Москвы” обнаружила либеральных фашистов в собственных рядах, [в:] электронный ресурс: http:// politrussia.com/opozitsiya/zhurnalistka-ekha-moskvy-419/

История фашизма в Западной Европе, Москва 1978.

К а л а ч и х и н а Ю., Каддафи отправил Запад на „свалку истории”, [в:] электронный реcypc: http://www.rbcdaily.ru/2011/03/23/world/562949979918858.shtml (23.03.2011). 
К о с т о м а р о в В. Г., Языковой вкус эпохи, Москва 1994.

Лукоморье, [в:] электронный ресурс: https://lurkmore.to/\%D0\%A4\%D0\%B0\%D1\%8 $8 \% \mathrm{D} 0 \% \mathrm{~B} 8 \% \mathrm{D} 1 \% 81 \% \mathrm{D} 1 \% 82$

Национальный корпус русского языка, [в:] электронный ресурс: www.ruscorpora.ru

Н о й м а н н Ф. Л., Бегемот. Структура и практика национал-социализма. 1933-1944, Санкт-Петербург 2015.

Н о л ь т е Э., Фашизм в его эпохе, Новосибирск 2001.

Н осико в Р., Капитализм и Глобальное Зло. Рецензия на „Мсителей-2”, [в:] электронный ресурс: http://www.odnako.org/blogs/kapitalizm-i-globalnoe-zlo-recenziyana-mstiteley-2/

„Особое мнение" 28 мая 2014 г., [в:] электронный pecypc: http://echo.msk.ru/ programs/personalno/1329372-echo/

Р а тм ай р Р., Русская речь и рынок: традиции и инновации в деловом и повседневном общении, Москва 2013.

Русский язык кониза ХХ столетия, отв. ред. Е. А. Земская, 2-е изд., Москва 2000.

Словарь русского языка: $b$ 4-х т., под ред. А. П. Евгеньевой, 2-е изд., испр. и доп., т. 4, Москва 1981-1984, с. 556.

Словарь современного русского литературного языка: 8 17-ти т., т. 16, Москва 1948-1965, c. 1285.

Современный русский язык. Активные процессы на рубеже ХХ-ХХІ веков, отв. ред. Л. П. Крысин, Москва 2008.

Современный русский язык: система-норма-узус, отв. ред. Л. П. Крысин, Москва 2010.

Современный русский язык: социальная и функциональная дифференциация, отв. ред. Л. П. Крысин, Москва 2003.

Темные силы против Масленицы, „Народное творчество” 2004, [в:] электронный реcypc: www.ruscorpora.ru

Толковый словарь русского языка: $b$ 4-х т., под ред. Д. Н. Ушакова, т. 4, Москва 1996, c. 1064.

Толковый словарь русского языка начала ХХІ века: актуальная лексика, под ред. Г. Н. Скляревской, Москва 2008, с. 1020.

Электронный ресурс: https://otvet.mail.ru/question/20705322 (23.03.2011).

Электронный ресурс: https://otvet.mail.ru/question/10993861 (23.03.2011).

Электронный ресурс: https://otvet.mail.ru/question/50979100 (23.03.2011).

G r i f f i n R., The Nature of Fascism, London 1993.

Wikipedia, [в:] электронный ресурс: https://en.wikipedia.org/wiki/Liberal_Fascism 